\title{
Deficiency of the second complement component: association with the HLA haplotype A10, B18 in a normal population *
}

\author{
RICHARD I. RYNES, ANTHONY F. H. BRITTEN, AND \\ RICHARD J. PICKERING
}

From the Departments of Medicine (Division of Rheumatology), Microbiology-Immunology and Pediatrics, Albany Medical College; New York State Kidney Disease Institute (Unit of New York State Department of Health); and the American Red Cross Blood Services, Northeastern New York Region, Albany, New York

SUMMARY Serum C2 activity was measured in 135 individuals drawn from a panel of 418 tissuetyped blood donors. The study group included all donors with HLA antigens A10 and B18. Heterozygote $\mathrm{C} 2$ deficiency $\left(\mathrm{C} 2 \mathrm{D}_{\text {het }}\right)$ was defined by reference to the range of $\mathrm{C} 2$ activity in previously studied obligate heterozygotes. Five donors were $C 2 \mathrm{D}_{\text {het }}$. Family studies confirmed that $C 2 \mathrm{D}_{\text {het }}$ was associated in all instances with an A10, B18 haplotype. The minimum frequency for $\mathrm{C}_{2} \mathrm{D}_{\text {het }}$ was $1.2 \%$ in the panel of 418 donors and $62.5 \%$ in those donors with an A10, B18 haplotype.

Individuals with either homozygous or heterozygous deficiency of the second component of complement $\left(C 2 D_{\text {hom }}\right.$ or $\left.C 2 D_{\text {het }}\right)$ develop connective tissue disease, particularly systemic lupus erythematosus (SLE), significantly more frequently than individuals in the general population. ${ }^{12}$ In man the $\mathrm{C} 2$ gene is located on chromosome 6 adjacent to or within the major histocompatibility complex (MHC). The null gene for $\mathrm{C} 2$, causing $\mathrm{C} 2 \mathrm{D}$, has been reported to be associated with the HLA haplotype A10, B18, DW2 in patients with SLE and in their families. ${ }^{13}$ The significance of these associations remains unexplained. $\mathrm{C} 2$ deficiency per se may impair host immune response, facilitating development of the disorder. Alternatively, it is possible that C2D is merely a marker for a putative MHC region immune response gene which is related to pathogenesis of SLE. Since the associations among SLE, C2D, and the HLA antigens A10, B18, and DW2 are not invariable, ${ }^{3-8}$ other predisposing factor(s) may be involved.

To assess better the meaning of the association of C2D and histocompatibility antigens with SLE it is important to know the association of C2D with

*Presented before the Heberden Society Annual Meeting, November 1980.

Accepted for publication 29 January 1981.

Correspondence to Richard I. Rynes, MD, Room ME407, Albany Medical College, Albany, New York 12208, USA.
HLA genes in individuals without disease. We have therefore assessed the frequency of C2D in a normal population who had previously been tissue typed and studied the relation between C2D and HLA antigens. In this group we found $C 2 D_{\text {het }}$ with a minimum frequency of $1 \cdot 2 \%$. All individuals with C2D het had an A10, B18 haplotype.

\section{Materials and methods}

A total of 135 subjects were selected from a panel of 418 predominantly Caucasian blood donors who had previously been tissue typed at the American Red Cross Blood Services, Northeastern New York region. Each of the 8 individuals with both A10 and $B 18$ antigens were studied. Eleven of 21 subjects with A10 antigen (but not B18) and 14 of 35 with B18 antigen (but not A10) were available for $\mathrm{C} 2$ testing. Blood samples were also drawn from 102 of the remaining 354 donors as they randomnly came to donate blood. This latter group was not preselected on the basis of tissue type. Blood was refrigerated immediately after collection, allowed to clot, and the serum frozen at $-70^{\circ}$ until analysed for $\mathrm{C} 2$ activity.

Tissue typing was performed by the microlymphocytotocity method ${ }^{9}$ using antisera from the National Institutes of Health (NIH) and the American, Netherlands, and Canadian Red Cross. 
At least 2 antisera were used for each antigen tested. The HLA A10 antigen embraces the specificities A25 and A26, which we shall list in parentheses when the antigen could be further defined. Initial testing for A10 and A25 included one antiserum from NIH and one antiserum from the Red Cross for each antigen; both antisera against A26 were from Red Cross sources. Five additional antisera were used in an effort to try to define further the A10 antigen in cells of available subjects and parents who had both A10 and B18 antigen. B18 antigen was determined with antisera from NIH and the American Red Cross.

C2 activity was determined by previously published methods. ${ }^{6}$ Normal C2 levels for this laboratory had been determined from 62 normal young adults. In addition the range of $C 2 D_{\text {het }}$ activity was determined from a group of 9 obligate heterozygotes including parents and children of $C 2 \mathrm{D}_{\text {hom }}$ individuals. In order to assess the possible genetic transmission of the low $\mathrm{C} 2$ activity and its association with the haplotype A10, B18, C2 assays and HLA typing were performed on available parents of Red Cross donors whose $\mathrm{C} 2$ levels were in the obligate heterozygote range. All $\mathrm{C} 2$ activities were determined and $C 2 D_{\text {het }}$ individuals identified without prior knowledge of any individual's tissue type. Appropriate controls were included each time $\mathrm{C} 2$ activity was determined.

All subjects were A10 and/or B18 antigens were questioned about a history of arthritis, skin rashes, sun sensitivity, Raynaud's phenomenon, or unexplained fever. In subjects with low $\mathrm{C} 2$ levels, $\mathrm{C} 1 \mathrm{~s}$ inhibitor and $\mathrm{C} 4$ protein levels were determined by Mancini radial immunodiffusion tests, ${ }^{10}$ antinuclear antibodies were measured by a fluorescent method using mouse liver as the substrate, and rheumatoid factor was measured by latex fixation testing.

\section{Results}

$\mathrm{C} 2$ activity ranges and number of individuals with C2D het are listed in Table 1 for Red Cross donors with various HLA antigens, obligate $C 2 D_{\text {het }}$ subjects, and normal persons who had not been tissue typed. Five of the 135 Red Cross donors had C2 levels in the obligate $\mathrm{C} 2 \mathrm{D}_{\text {het }}$ range. All of these donors had the tissue antigens A10 and B18.

C2 levels and HLA haplotypes of Red Cross donors in the $C 2 D_{\text {het }}$ range and their parents, and $\mathrm{C} 2$ ranges for normals and obligate $\mathrm{C}^{2} \mathrm{D}_{\text {het }}$ individuals, are listed in Table 2. Studies done on parents of the 5 donors in the obligate C2D $_{\text {het }}$ range (Table 2) confirmed that in each case A10
Table 1 C2 activity ranges and number of individuals with $C 2 D_{\text {het }}$ in groups studied

\begin{tabular}{lrll}
\hline Group & $\begin{array}{l}\text { Number } \\
\text { studied }\end{array}$ & $\begin{array}{l}\text { C2 activity } \\
\text { range } \\
\text { (units/ml) }\end{array}$ & $\begin{array}{l}\text { Number of } \\
\text { C2D het } \\
\text { individuals }\end{array}$ \\
\hline Red Cross donors & 11 & $5520-7260$ & 0 \\
HLA A10 & 14 & $3700-8200$ & 0 \\
HLA B18 & 8 & $1800-7100$ & 5 \\
HLA A10 and B18 & 102 & $3620-9740$ & 0 \\
Other HLA antigens & 135 & $1800-9740$ & 5 \\
Total & 9 & $860-3600$ & 9 \\
Obligate C2D & 62 & $3320-10960^{*}$ & Not known \\
Normal persons & & $2960-8680 \dagger$ & Not known \\
\hline
\end{tabular}

*True range of $\mathrm{C} 2$ activity. †Mean \pm 2 standard deviations.

Table $2 C 2$ activity and HLA haplotypes for C2Dhet individuals and their parents

\begin{tabular}{|c|c|c|c|c|c|}
\hline \multirow[b]{2}{*}{ Subject } & \multicolumn{3}{|l|}{ Subjects } & \multicolumn{2}{|l|}{ Parents* } \\
\hline & $\begin{array}{l}\text { C2 } \\
\text { activity } \\
\text { (units/ml) }\end{array}$ & $\begin{array}{l}\text { HLA } \\
\text { haplotypes }\end{array}$ & & $\begin{array}{l}\text { C2 } \\
\text { activity } \\
\text { (units } / m l)\end{array}$ & $\begin{array}{l}\text { HLA } \\
\text { haplotypes }\end{array}$ \\
\hline \multirow[t]{2}{*}{$\mathbf{A}$} & \multirow[t]{2}{*}{3300} & \multirow[t]{2}{*}{$\begin{array}{l}\text { A10 (A25), } \\
\text { B18/A3, B14 }\end{array}$} & $\mathbf{M}$ & 2400 & \multirow{4}{*}{$\begin{array}{l}\text { A10 (A25), } \\
\text { B18/A2, B7 } \\
\text { A3, B14/A29, } \\
\text { B40 } \\
\text { A10, B18/A1, } \\
\text { B7 } \\
\text { A1, B17/A32, } \\
\text { B27 }\end{array}$} \\
\hline & & & $\mathbf{F}$ & 6760 & \\
\hline \multirow[t]{2}{*}{ B } & \multirow[t]{2}{*}{1800} & \multirow[t]{2}{*}{$\begin{array}{l}\text { A } 10, \mathrm{~B} 18 / \mathrm{A} 1, \\
\mathrm{~B} 17\end{array}$} & $\mathbf{M}$ & 2260 & \\
\hline & & & $\mathbf{F}$ & 7120 & \\
\hline \multirow[t]{2}{*}{ C } & \multirow[t]{2}{*}{2740} & \multirow[t]{2}{*}{$\begin{array}{l}\text { A10, B18/A29, } \\
\text { B12 }\end{array}$} & $\mathbf{M}$ & 2840 & \multirow{6}{*}{$\begin{array}{l}\text { A10 (A25), } \\
\text { B18/A9 (A24), } \\
\text { B5 } \\
\text { A10, B18/A2, } \\
\text { BW35 } \\
\text { A10 (A26), } \\
\text { B7/X, B27 } \\
\text { A10 (A25), } \\
\text { B18/A2, B5 } \\
\text { A3, B7/A2, B12 }\end{array}$} \\
\hline & & & $\mathbf{F}$ & Dac. & \\
\hline \multirow[t]{2}{*}{ D } & \multirow[t]{2}{*}{2680} & \multirow[t]{2}{*}{$\begin{array}{l}\text { A10, B18/A10 } \\
\text { (A26), B7 }\end{array}$} & $\mathbf{M}$ & 2400 & \\
\hline & & & $\mathbf{F}$ & 5520 & \\
\hline \multirow[t]{2}{*}{$\mathbf{E}$} & \multirow[t]{2}{*}{2580} & \multirow[t]{2}{*}{$\begin{array}{l}\text { A } 10, \mathrm{~B} 18 / \mathrm{A} 3 \text {, } \\
\mathrm{B} 7\end{array}$} & $\mathbf{M}$ & 2600 & \\
\hline & & & $\mathbf{F}$ & 4800 & \\
\hline
\end{tabular}

Obligate C2D heterozygote range $=860-3600 \mathrm{units} / \mathrm{ml}$. Normal C2 level (mean \pm 2 standard deviations) $=2960-8680$.

${ }^{*} \mathbf{M}=$ mother, $\mathbf{F}=$ father, Dec. $=$ deceased.

and B18 antigens were a haplotype and were associated with low $\mathrm{C} 2$ levels. Initial tissue typing on donors $\mathrm{C}$ and $\mathrm{E}$ revealed $\mathrm{A} 10$ antigen which could not be further defined. These donors were not available to be retyped after their mothers were shown to have A25 specificity. The father of donor D showed only A26 antigen at the A locus; the mother had an A10 antigen which could not be further defined. This donor was believed to have HLA haplotypes of A10, B18 inherited from his mother and A10 (A26), B7 inherited from his father.

None of the 11 donors with HLA A10 antigen (but without B18), the 14 donors with B18 antigen (but without A10), nor the 102 randomly selected donors without $\mathrm{A} 10$ or B18 antigens had $\mathrm{C} 2$ levels in the $C 2 D_{\text {het }}$ range (Table 1). The association of C2D het with the HLA antigens A10 and B18 was 
highly significant compared with that in the other 127 donors tested $\left(\mathrm{p}=1.6 \times 10^{-7}\right.$ by Fisher's exact test).

None of the five individuals with $\mathrm{C} 2 \mathrm{D}_{\text {het }}$ gave a history of symptoms of connective tissue disease or recurrent infections. They had normal $\mathrm{Cls}$ inhibitor and $\mathrm{C} 4$ levels, and tests for rheumatoid factor and antinuclear antibody were negative.

\section{Discussion}

An association of C2D with tissue antigens A10 and $\mathrm{B} 18$ was expected on the basis of previous reports concerning C2D in families usually identified by a propositus with $\mathrm{C}_{2} \mathrm{D}_{\text {hom }}$ and connective tissue disease. ${ }^{1}$ However, it was impressive to find that among the individuals in an apparently normal population at least $62.5 \%$ of those with $\dot{A} 10, \mathrm{~B} 18$ haplotype were $\mathrm{C} 2 \mathrm{D}_{\text {het. }}$. The A10, B18 haplotypes of these 5 individuals were established by family studies (Table 2). From these data we can estimate, with $95 \%$ confidence limits, that between $24.5 \%$ and $91.5 \%$ of individuals with an A10, B18 haplotype carry the null $\mathrm{C} 2$ gene. The estimate could be even higher if the A10 and B18 tissue antigens in any of the other 3 individuals with normal $\mathrm{C} 2$ levels are not present as a haplotype. The frequency found is similar to an estimate in a Danish population in which family studies were not performed for most subjects. ${ }^{11}$ It was equally striking in our study that all individuals who were $\mathrm{C}_{2} \mathrm{D}_{\text {het }}$ had an A10, B18 haplotype. Although C2D was not associated with other haplotypes in our study, it has occurred with other haplotypes in some families in which the propositus has $\mathrm{C}^{2} \mathrm{D}_{\text {hom }}$ associated with SLE. ${ }^{4-6}$

The minimum frequency of $\mathrm{C}_{2} \mathrm{D}_{\text {het }}$ among the full panel of 418 donors was $1 \cdot 2 \%$. On the basis of a hypergeometric distribution and from our results derived from the 135 individuals tested, the frequency of $C 2 D_{\text {het }}$ might be as high as $2.9 \%(95 \%$ confidence limits) in the population sampled. A frequency of $1.2 \%$ is in agreement with a previous study $^{2}$ in which neither tissue typing nor family studies were performed on the normal population. Our data suggest that about $1 / 28000$ individuals in the general population would be expected to have C2D hom. This frequency is consistent with a previous study in which one $\mathrm{C}_{2} \mathrm{D}_{\text {hom }}$ individual was found among 10000 people tested. ${ }^{12}$

C2D $D_{\text {het }}$ individuals are generally identified by having $\mathrm{C} 2$ activity more than 2 standard deviations below the normal mean. This criterion would have incorrectly placed one of our abnormal values in the normal range (Donor A, Table 2). However, we had established our $\mathrm{C} 2 \mathrm{D}_{\text {het }}$ range by determining $\mathrm{C} 2$ activity in a group of individuals who were obligate carriers of the null $\mathrm{C} 2$ gene by virtue of having either a parent or child with C2D hom. This approach established a higher limit for $C 2 D_{\text {het, }}$ and so identified donor $\mathrm{A}$ as a $\mathbf{C} 2 \mathrm{D}_{\text {het }}$ individual. His status was confirmed by family studies. The statistically derived normal range extends into our range, derived from obligate heterozygotes, because some normal persons may have high C2D levels and/or some individuals with $C 2 D_{\text {het }}$ may be included among the controls. Although initial screening for $\mathrm{C} 2 \mathrm{D}_{\text {het }}$ can be done by C2 assay, family studies are needed to confirm the deficiency.

Our finding of $\mathrm{C} 2 \mathrm{D}_{\text {het }}$ only in individuals with an HLA A10, B18 haplotype with a frequency of association similar to that in another study, ${ }^{11}$ as well as a population frequency of $1.2 \%$, which is the same as that noted by another group which also used a Red Cross donor control population, ${ }^{2}$ suggests that in healthy populations $\mathrm{C} 2 \mathrm{D}$ is predominantly associated with the A10, B18 haplotype. This association is also found in patients with heterozygous or homozygous C2D and SLE. ${ }^{12}$ The presence of linkage disequilibrium in both normal persons and patients fails to implicate selectively either C2D or related major histocompatibility region genes in the pathogenesis of disease. Recent evidence that more than one gene may be involved in the development of SLE ${ }^{13}$ suggests that complement deficiency or a related MHC region gene may influence disease pathogenesis only in individuals with another, yet unknown, predisposing factor.

The authors thank Ms C. Conners and Ms. J. Jones for their technical help and assistance in implementing this study, Ms N. LoCascio for her excellent technical assistance, Dr R. Regal for assistance with statistics, and Ms D. Havel for manuscript preparation. The assistance of Dr A. H. Grindon, Director, and the staff of the Atlanta Region of the American Red Cross Blood Services is gratefully acknowledged for serum collection and HLA typing of the parents of individual A.

\section{References}

1 Agnello V. Complement deficiency states. Medicine 1978; 57: 1-23.

2 Glass D, Raum D, Gibson D, Stillman J S, Schur P H. Inherited deficiencies of the second component of complement. J Clin Invest 1976; 58: 953-861.

3 Fu S M, Stern R, Kunkel H G, et al. LD-7a association with $\mathrm{C2}$ deficiency in five of six families. In: KissmeyerNielson F. Histocompatibility Testing. Copenhagen: Munksgaard, 1975: 933-6.

4 Wolski K P, Schmid F R, Mittal K K. Genetic linkage between HL-A system and a deficit of the second component (C2) of complement. Science 1975; 188: 1020-2.

5 Dantant M, Rivat C, Gilbert D, et al. Selective deficiencies in complement component: a family with hereditary C2 deficiency. Biomedicine 1978; 28: 185-90. 
6 Rynes R I, Urizar R E, Pickering P J. Genetic deficiency of the second component of complement (C2) associated with systemic lupus erythematosus: relation of the complement abnormality and disease manifestations. Am J Med 1977; 63: 279-88.

7 Rynes R I, Urizar R E, Pickering P J. Heterogeneity of the clinical syndrome in patients with systemic lupus erythematosus and genetic deficiency of the second complement component. Clin Exp Immunol 1978; 32: 59-68.

8 Klemperer M R, Woodworth H C, Rose F S, et al. Hereditary deficiency of the second component of complement (C2) in man. J Clin Invest 1966; 45: 880-90.
9 Terasaki P I, Bernoco D, Park M S, Ozturk G, Iwaki Y. Micro-droplet testing for HLA-A, -B, -C, and -D antigens. Am J Clin Pathol 1978; 69: 103-20.

10 Mancini G, Carbonara A O, Heremans J F. Immunochemical quantitation of antigens by single radial immunodiffusion. Immunochemistry 1965; 2: 235-54.

11 Mortensen J F, Buskjaer L, Lamm L U. Studies on the C2-deficiency gene in man. Immunology 1980; 38: 541-9.

12 Lachmann P G. Genetic deficiencies of the complement system. Boll 1st Sieroter Milan (suppl) 1974; 53: 195-207.

13 Miller K B, Schwartz R S. Familial abnormalities of suppressor-cell function in systemic lupus erythematosus. N Engl J Med 1979; 301 : 541-9. 